\title{
ПОРІВНЯННЯ ПАРАМЕТРІВ АСИНХРОННИХ ТА СИНХРОННИХ ЕЛЕКТРОГЕНЕРАТОРІВ ЗІ ЗБУДЖЕННЯМ ВІД ПОСТІЙНИХ МАГНІТІВ ДЛЯ ВІТРОУСТАНОВОК
}

\author{
Ю.Н. Перминов ${ }^{1}$, канд. техн. наук, Н.В. Марченко ${ }^{1}$, С.Ю. Перминова ${ }^{2}$ \\ ${ }^{1}$ Інститут відновлюваної енергетики НАН України, \\ 02094, вул. Гната Хоткевича, 20А, м. Київ, Україна. \\ ${ }^{2}$ Інститут екологічного управління та збалансованого природокористування, \\ 04050, вул. Ю. Іллєнка, 81, корп. 20, м. Київ, Україна.
}

У статті на основі характеристик деяких вітрових зон Украӥни [1] та швидкості вітру, яка застосовується при проєктуванні в Украӥні й за кордоном, проведено порівняння основних параметрів вітроустановок різних конструкцій, які мають найбільше застосування. Для иъього за певним алгоритмом [2-7] був розрахований ряд синхронних генераторів потужністю від 600 до 3600 кВт з урахуванням потужності машин, які випускаються ТОВ «Завод крупних електричних машин» (м. Каховка, Україна). Показана також конструкція генераторів иього заводу після заміни в них асинхронних двигунів на синхронні двигуни зі збудженням від постійних магнітів. Визначено перспективність використання постійних магнітів в системах збудження синхронних генераторів.

Відзначено, щзо при такому підході до створення синхронних електрогенераторів для вітроустановок потрібне обов'язкове застосування мультиплікаторів для забезпечення частоти обертання, яка відповідає частоті обертання вихідного двигуна. Другою умовою є відповідність індукиії в робочому зазорі не нижче 0,7-0,8 Тл. Для иього необхідне використання магнітів типу $\mathrm{NdFeB}$, що відрізняються високою питомою енергією та дають змогу спростити конструкцію, усунути втрати на збудження, які притаманні генераторам з електромагнітним збудженням, підвищити ККд і надійність генераторів.

Застосування мультиплікаторів вимагає їх обов'язкового регулярного обслуговування $і$ знижує надійність електроагрегату. У зв'язку з иим була розглянута оригінальна конструкиія безредукторного генератора зі збудженням від постійних магнітів. Особливість иієї конструкції генератора полягає у відсутності ярма статора та мультиплікатора, а також корпусу генератора.

Корпусом генератора є шихтований пакет статора, $і$ в иілому генератор являє собою модуль у складі головки вітроустановки, щцо дозволяе істотно зменшити його масу. В статті обтрунтовано доиільність застосування безкорпусноі модульної конструкції вітроустановки зі збудженням від постійних магнітів без мультиплікатора та проведено порівняння параметрів вітроустановок зазначених конструкцій. Бібл. 9, табл. 4, рис. 3.

Ключові слова: вітроустановка, синхронний генератор зі збудженням від постійних магнітів, постійні магніти.

\section{COMPARISON OF PARAMETERS OF ASYNCHRONOUS AND SYNCHRONOUS ELECTRIC GENERATORS WITH PERMANENT MAGNETS EXCITATION FOR WIND TURBINES}

\author{
Y. Permynov ${ }^{1}$, candidate of technical science, N. Marchenko ${ }^{1}$, S. Permynova ${ }^{2}$ \\ ${ }^{1}$ Institute of Renewable Energy of the National Academy the Sciences of Ukraine, \\ 02094, Hnata Khotkevycha, 20A, Kyiv, Ukraine. \\ ${ }^{2}$ Institute for Environmental Management and Balanced Nature, \\ 04050, Y. Illienka Str., 81, build. 20, Kyiv, Ukraine.
}

The article compares the main parameters of wind turbines whith various designes based on the characteristics of some wind zones in Ukraine [1] and the wind speed used in their design in Ukraine and in the world. For this purpose, according to a certain algorithm [2-7], a number of synchronous generators with a power of 600 to $3600 \mathrm{~kW}$ were evaluated with a reference to the capacity of machines produced by Large Electric Machines Plant LLC (Kakhovka, Ukraine). The construction of the machines produced by this plant after their conversion from asynchronous motors to synchronous generators with permanent magnet excitation is shown. The prospects of using permanent magnets in excitation systems of synchronous generators are determined.

It is noted that according to this approach to the synchronous wind turbines design, the mandatory use of multipliers is required to ensure the rotation frequency corresponding to the rotation frequency of the converted induction motors. The second condition is the 
compliance of the induction in the working gap not lower than $0.7-0.8$ T. This requires the use of high energy density magnets, such as the NdFeB. This type of magnets also allows to simplify the design, eliminate the excitation losses that are inherent in generators with electromagnetic excitation and to increase the generators efficiency and reliability.

The use of multipliers requires their mandatory service and reduces the generating set reliability. In this regard, the original design of a gearless permanent magnet generator was considered. The design feature of this generator is the absence of the stator yoke and multiplier, as well as the generator housing.

The generator housing is a laminated stator package and, in general, the generator is a part of the wind turbine head, thus, its weight can be reduced significantly. The article substantiates the expediency of using a caseless modular design of a wind turbine with excitation from permanent magnets without a multiplier and compares wind turbines parameters with the mentioned design. Ref. 9 , table 4, fig. 3.

Keywords: wind turbine, permanent magnets synchronous generator, permanent magnets.

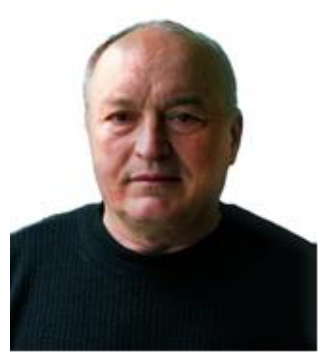

Ю.М. Перминов

Y. Permynov

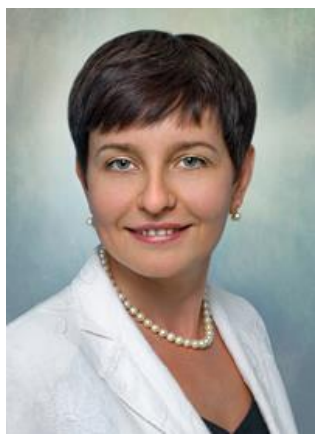

Н.В. Марченко N. Marchenko

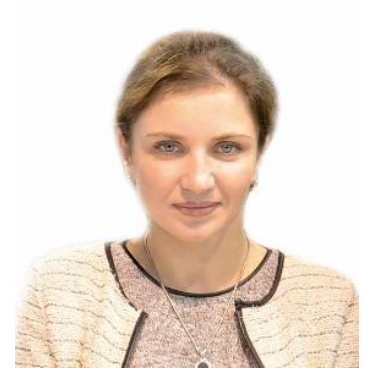

С.Ю. Перминова S. Permynova
Відомості про автора: канд. техн. наук, старший науковий співробітник Інституту відновлюваної енергетики НАН України Освіта: Київський політехнічний інститут, спеціальність «Електричні машини та апарати»

Наукова сфера: вітроустановки, гідрогенератори, пристрої з постійними магнітами

Публікації: 89

ORCID: $10000-0001-5604-8327$

Контакты: тел/факс +38-044-206-28-09

e-mail: renewable@ukr.net

Відомості про автора: молодший науковий співробітник з питань маркетингових досліджень Інституту відновлюваної енергетики НАН України

Освіта: Київський технологічний інститут легкої промисловості, спеціальність «Інженер-конструктор-технолог» Наукова сфера: маркетинговий аналіз інноваційної діяльності в галузі відновлюваної енергетики, вітроустановки, пристрої $з$ постійними магнітами

Публикації: 33

ORCID: 0000-0001-9921-9077

Контакти: тел/факс:+38-098-408-26-02

e-mail: nadija08@ukr.net

Відомості про автора: керівник відділу науково-методичного забезпечення Інституту екологічного управління та збалансованого природокористування

Освіта: Київський національний університет будівництва і архітектури, спеціальність «Екологічна безпека»

Наукова сфера: відновлювані джерела енергії, зелене будівництво; екологічний менеджмент, аудит та оцінка життєвого циклу продукції (ISO 14000)

Публікації: 27

ORCID: 0000-0003-0550-6548

Контакти: тел/факс: +38-067-935-82-45

e-mail: info@iem.org.ua
Author information: candidate of technical sciences, Senior Researcher at the Institute of Renewable Energy of the National Academy of Sciences of Ukraine

Education: Kiev Polytechnic Institute, specialty Electrical Machines and Apparatuses

Research area: wind power systems, wind turbines, hydrogenerators, permanent magnets devices

Publications: 89

ORCID: $10000-0001-5604-8327$

Contacts: phone/fax:+38-044-206-28-09

e-mail: renewable@ukr.net

Author information: Junior Researcher on marketing research at the Institute of Renewable Energy of the National Academy of Sciences of Ukraine

Education: Kyiv National University of Technologies and Design, specialty Design Engineer - Technologist

Research area: marketing research in the field of renewable energy innovations; wind turbines, permanent magnets devices

Publications: 33

ORCID: 0000-0001-9921-9077

Contacts: phone/fax:+38-098-408-26-02

e-mail: nadija08@ukr.net

Author information: Head of the Department for Scientific and Methodological Support at the Institute for Environmental Management and Balanced Nature

Education: Kyiv National University of Construction and Architecture, specialty Environmental Safety

Research area: renewable energy sources, green building; environmental management, audit and life cycle assessment (ISO 14000)

Publications: 27

ORCID: 0000-0003-0550-6548

Contacts: phone/fax: +38-067-935-82-45

e-mail: info@iem.org.ua 
Перелік використаних позначень та скорочень:

$M e$ - електромагнітний момент;

$P$ - потужність генератора;

$A$ - лінійне навантаження;

$B_{\delta}$ - індукція в робочому зазорі;

$D_{p}$ - діаметр ротора;

$l_{a}$ - активна довжина ротора;

$l_{m}$ - активна довжина магніту;

$p^{\prime}$ - кількість пар полюсів магніту;

$\rho$ - щільність повітря;

$v$ - швидкість повітряного потоку;

Вступ. У процесі розвитку вітроенергетики в установках застосовувалися різні типи генераторів. Основними вимогами до генераторів $€$ : висока питома потужність, яка визначається відносно маси або габаритів електроагрегату, тому що це зумовлює вимоги до міцності опори, ціну установки і вартість одиниці виробленої електроенергії (кВт); надійність роботи в складних кліматичних умовах. Внаслідок цього колекторні та синхронні генератори 3 електромагнітним збудженням мають обмежене застосування, що пояснюється наявністю контакту ковзання й необхідністю обслуговування щіткового вузла. Більш широко застосовуються асинхронні генератори 3 мультиплікаторами, синхронні генератори зі $k$ - ККД ротора;

$\eta$ - ККД генератора;

$\varpi$ - кутова швидкість обертання;

$z^{\prime}$ - коефіцієнт швидкохідності;

$S$ - площа захопленої поверхні;

$f$ - частота напруги;

$\alpha_{i}-$ коефіцієнт полюсного перекриття;

$E P C$ - електрорушійна сила;

ККД - коефіцієнт корисної дії;

$\kappa B m-$ кіловат.

збудженням від постійних магнітів. Використання постійних магнітів 3 високою питомою енергією типу $\mathrm{NdFeB}$ дає змогу підвищити енергетичні показники за рахунок усунення втрат на збудження, спростити конструкцію, підвищити надійність агрегату.

Постановка задачі. У статті проведено порівняння електричних генераторів для вітроустановок зі збудженням від постійних магнітів, виготовлених на базі серійних асинхронних двигунів і мультиплікаторів 3 генераторами модульної конструкції.

У табл. 1 наведені загальні параметри електроагрегатів різних конструкцій, що дозволяють провести їх порівняльну оцінку.

Таблиця 1. Порівняльні характеристики електрогенераторів для вітроустановок

Table 1. Comparative characteristics of electric generators for wind turbines

\begin{tabular}{|c|c|c|c|c|c|c|}
\hline Тип генератора & $\begin{array}{c}\text { ККД, } \\
\eta\end{array}$ & $\begin{array}{c}\text { Діапазон } \\
\text { потужності, } \\
\text { кВт }\end{array}$ & Маса, кг & $\begin{array}{c}\text { Вартість, } \\
\text { у.о. } \\
\text { за } 1 \text { кВт }\end{array}$ & $\begin{array}{l}\text { Надій- } \\
\text { ність }\end{array}$ & Загальна характеристика \\
\hline Колекторний & 0,87 & до 200 & до 1500 & - & знижена & $\begin{array}{l}\text { Наявність } \\
\text { колекторного вузла, який } \\
\text { вимагає } \\
\text { обслуговування }\end{array}$ \\
\hline $\begin{array}{l}\text { Асинхронний } 3 \\
\text { мультиплікатором }\end{array}$ & 0,89 & до 4000 & $\begin{array}{l}\text { до } \\
40 \times 10^{3}\end{array}$ & - & висока & $\begin{array}{l}\text { Надійні, проте } \\
\text { потребують } \\
\text { обслуговування } \\
\text { мультиплікатора }\end{array}$ \\
\hline $\begin{array}{l}\text { Синхронний } 3 \\
\text { електромагнітним } \\
\text { збудженням }\end{array}$ & 0,87 & $160-630$ & до 4500 & - & знижена & $\begin{array}{l}\text { Наявність } \\
\text { збудження, } \quad \text { джерела } \\
\text { ковзання; поктів } \\
\text { обслуговування, } \\
\text { знижує надійність }\end{array}$ \\
\hline $\begin{array}{l}\text { Синхронний зі } \\
\text { збудженням від } \\
\text { постійних магнітів без } \\
\text { мультиплікатора }\end{array}$ & 0,95 & до 7000 & $\begin{array}{l}\text { від } 8 \text { до } \\
40 \times 10^{3}\end{array}$ & $\approx 1000$ & висока & $\begin{array}{l}\text { Надійні; не потребують } \\
\text { систематичного } \\
\text { обслуговування; дорогі } \\
\text { через високу вартість } \\
\text { магнітів NdFeB }\end{array}$ \\
\hline
\end{tabular}


Останніми роками у вітроустановках широко застосовуються синхронні електрогенератори зі збудженням від постійних магнітів. Застосування постійних магнітів дає змогу спростити конструкцію, усунути втрати на збудження, які притаманні генераторам 3 електромагнітним збудженням, підвищити ККД і надійність генераторів. Це обумовлює використання постійних магнітів як в машинах малої потужності, так і в машинах з потужністю в кілька мегават.

При цьому можливе виготовлення таких генераторів на базі серійних асинхронних двигунів, що їх випускають декілька заводів в
Україні: ТОВ «Завод крупних електричних машин» i TOB «Новокаховський електромашинобудівний завод» в м. Каховка, АТ «Елекромашина» в м. Харків та інші. Такий варіант генераторів дозволяє вирішити задачу виробництва в найкоротші терміни 3 використанням серійних мультиплікаторів i переробкою тільки роторів серійних машин із заміною короткозамкненої обмотки ротора («білячої клітини») магнітами типу $\mathrm{NdFeB}$ (рис. 1), що дозволяє отримати індукцію в робочому зазорі на рівні 0,8 Тл, тобто не нижче, ніж при електромагнітному збудженні.
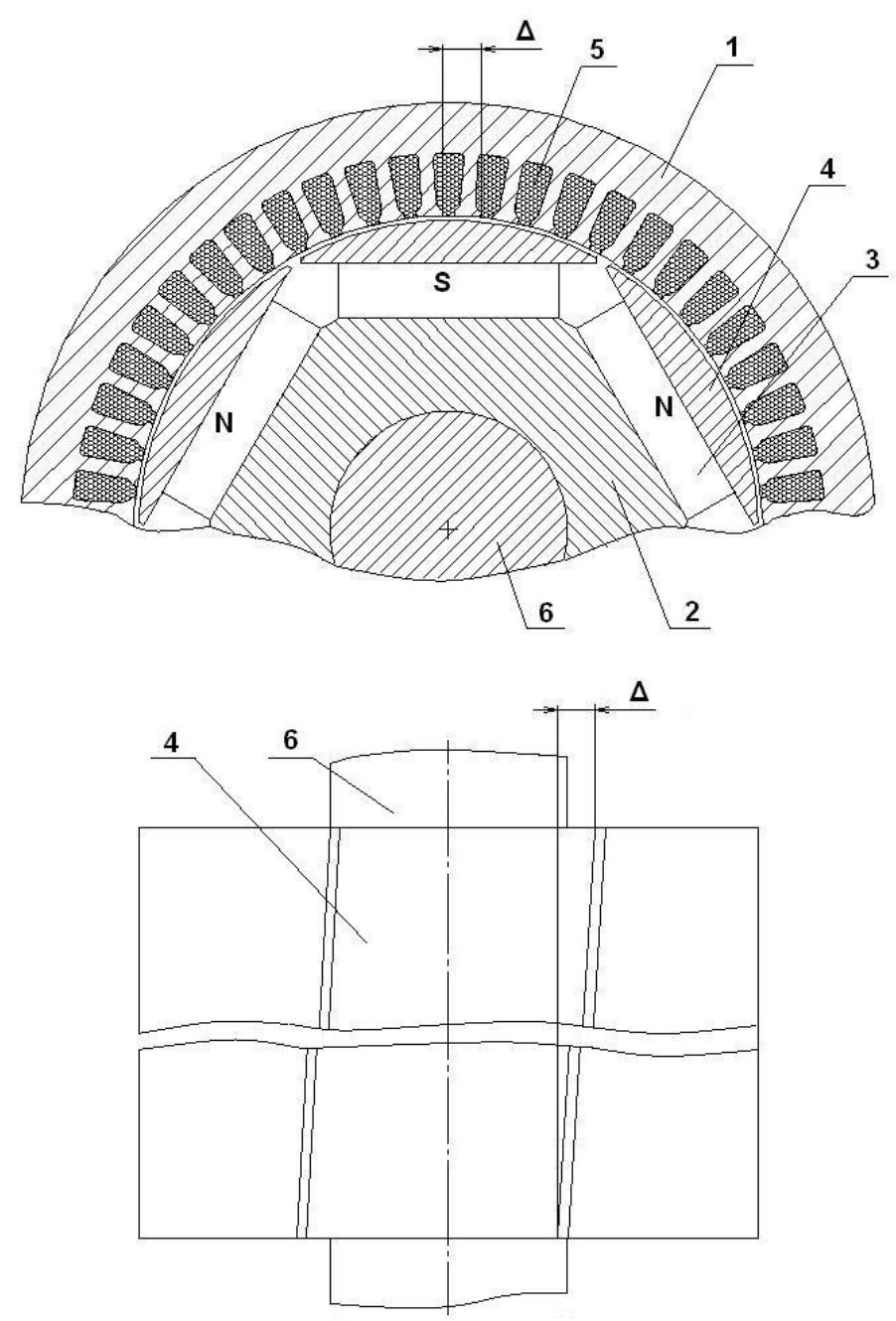

Рис. 1. Синхронний генератор зі збудженням від постійних магнітів на базі серійного асинхронного двигуна: 1 - пакет статора; 2 - ярмо ротора; 3 магніт; 4 - металевий сегмент; 5 - обмотка; 6 - вал; $\Delta$ - крок

Fig. 1. Synchronous generator with permanent magnet excitation based on a serial asynchronous motor: 1 - stator package; 2 - rotor yoke; 3 - magnet; 4 - metal segment; 5 - winding; 6 - shaft; $\Delta$ - step 
Особливість

цієї

конструкції вітроустановки (див. рис. 1), на відміну від вітроустановки зі звичайними синхронними генераторами, полягає в розширеній полюсній дузі - 3 максимальним використанням об'єму ротора під магніти. Це дає змогу забезпечити максимальну величину корисного магнітного потоку. При цьому коефіцієнт полюсного перекриття, становить 0,85-0,87, що вище за аналогічний показник в звичайних електрогенераторах ( $\left.\alpha_{i} \approx 0,72\right)$, де він приймається таким 3 метою отримання синусоїдальної форми розподілу поля в робочому зазорі i, відповідно, ЕРС генератора.

У цьому разі усуваються гармоніки ЕРС, які викликають додаткові втрати в сталі ротора. В електрогенераторах 3 постійними магнітами збільшення корисного потоку можливе за рахунок збільшення площі робочого зазору і, відповідно, зменшення його магнітного опору.

$$
S_{\delta}=\frac{\pi D_{p}}{2 p^{\prime}} \cdot \alpha_{i} \cdot l_{m},(1)
$$

де $D_{p}$ - діаметр ротора; $p^{\prime}-$ кількість пар полюсів_магніту; $\alpha_{i}-$ коефіцієнт полюсного перекриття (при синусоїдальній напрузі приймає значення $\left.\alpha_{i} \approx 0,72\right) ; l_{m}$ - активна довжина магніту.

У вітроустановках зі збудженням від постійних магнітів збільшення коефіцієнта полюсного перекриття припустиме у зв'язку 3 тим, що при роботі на мережу необхідно застосовувати електрообладнання, яке дозволяє виконати вимоги мережі (зокрема такі, як рівність ЕРС генератора, частоти ЕРС генератора і мережі, синхронізація напруги мережі й фаз генератора). Виконання цих вимог при значних змінах швидкості вітрового потоку i, відповідно, частот обертання генератора, забезпечується електронікою: керованим випрямлячем, що зберігає випрямлену напругу генератора незмінною, незважаючи на зростання ЕРС обертання генератора 3 підвищенням швидкості вітру; конвертором, який підтримує необхідний рівень вихідної напруги постійного струму; інвертором, що перетворює напругу постійного струму в трифазний змінний струм.

Для додаткового збільшення площ робочого зазору, крім збільшення ширини магнітів, застосовуються металеві сегменти зі скосом (див. рис. 1) 3 мінімальною відстанню між ними. Це дозволяє зменшити реактивний момент, зумовлений зубцевою зоною. Потік розсіювання між металевими сегментами незначний через малу площу бічних поверхонь металевих сегментів протилежної полярності.

Взявши за основу параметри серійних асинхронних двигунів, ГСС-630К-ГСБ1100L потужністю від 300 до 3600 кВт, які випускаються ТОВ «Завод крупних електричних машин», був проведений розрахунок ряду синхронних електрогенераторів для вітроустановок відповідної потужності зі збудженням від постійних магнітів (табл. 2) 3 конструкцією роторів 3 мультиплікаторами (див. рис. 1), за наведеними нижче алгоритмами. При цьому параметри електрогенераторів розраховані 3 можливим застосуванням їх в Україні та за кордоном.

Згідно 3 картами вітрових зон, в Україні найбільший енергетичний потенціал спостерігається на півдні - в Криму та Карпатах, де середня швидкість вітру дорівнює 4,5-5 м/с (рис. 2). Також встановлено, що швидкість поривів вітру становить приблизно $20 \%$ середньої швидкості вітру, тому розрахункове значення швидкості вітру для України прийнято близько 8 м/с. За кордоном середнє розрахункове значення швидкості вітру прийнято 12-13 м/с 3 урахуванням використання вітростанцій у зонах 3 високими природними енергетичними потенціалами - на узбережжях морів і океанів, а також у таких зонах на материках. Потужність вітрового потоку визначається формулою: 


$$
P=\frac{\rho \cdot S \cdot v^{3} \cdot K}{2 \cdot \eta}
$$

де $v=12,5$ - розрахункова швидкість вітрового потоку, $M / c ; \rho=1,3$ - щільність повітря, $\kappa 2 / \mathcal{M}^{3} ;$ $S$ - площа захоплюваної поверхні ротора, $\mathrm{m}^{2}$;
$K \approx 0,38-0,4-$ ККД ротора; $\eta \approx 0,85-0,92-$ ККД генератора.

3 формули (2) визначається площа захоплюваної поверхні ротора:

$$
S=\frac{2 P \cdot \eta}{\rho \cdot v^{3} \cdot K}
$$

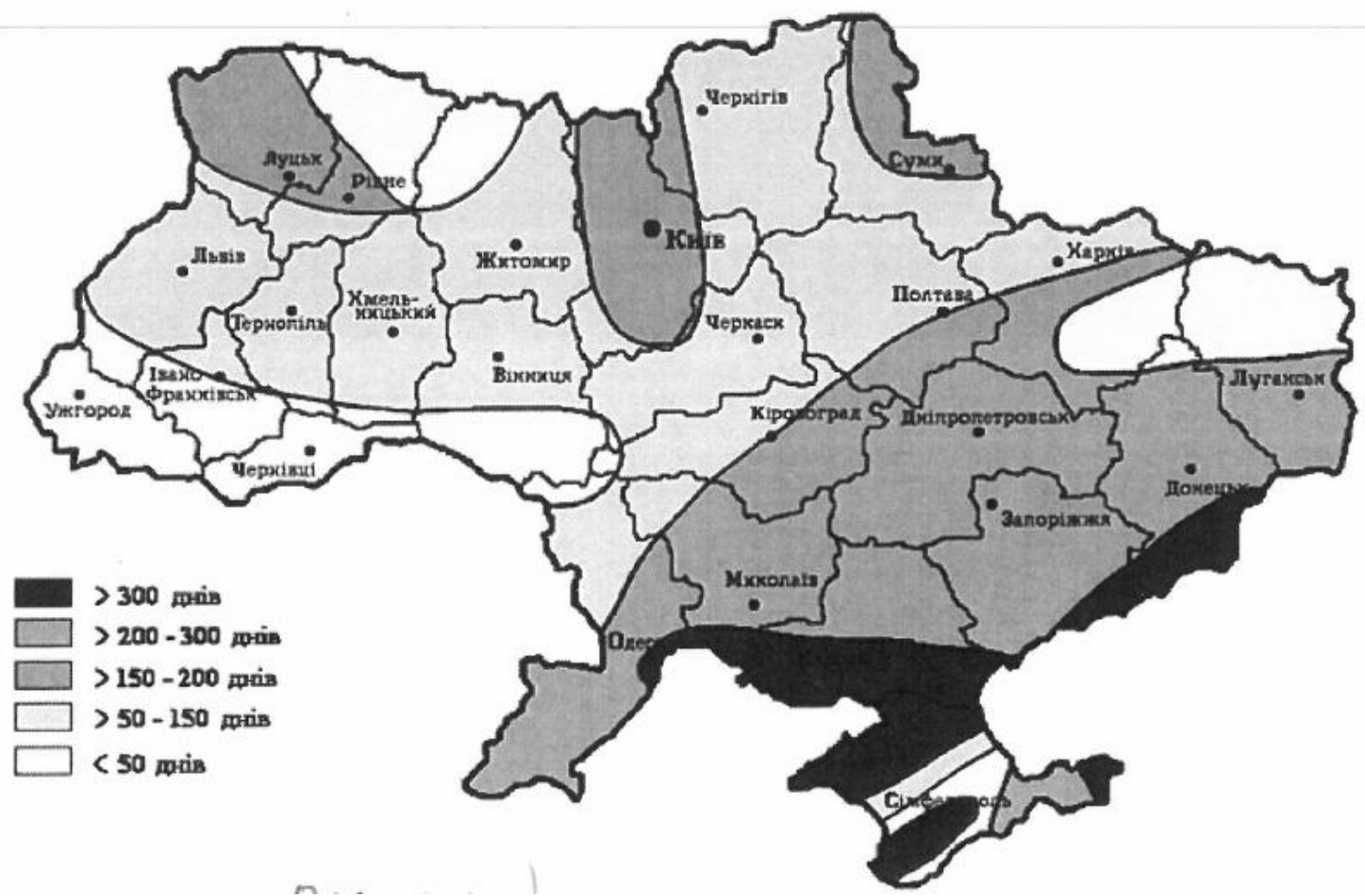

Рис. 2. Розподіл періоду використання енергії вітру в автономних системах

Fig. 2. Period of wind energy use in autonomous systems

Діаметр ротора вітроустановки, м:

$$
D=\sqrt{\frac{S}{0,785}},
$$

Кутова частота обертання ротора вітроустановки:

$$
\varpi=\frac{z^{\prime} \cdot v}{R},
$$

де $z^{\prime} \approx 4,6-6-$ коефіцієнт швидкохідності осьового ротора, який визначається як відношення лінійної швидкості обертання кінців лопатей ротора до швидкості повітряного потоку; $R$ - радіус ротора, м.
За кутовою частотою обертання (5) i заданою частотою вихідної напруги $3(f)$ визначається число пар полюсів магнітної системи генератора:

$$
p^{\prime}=\frac{60 \cdot f}{n},
$$

де $f=(50 ; 60)$ Гц - частота вихідної напруги; $n-$ частота обертання ротора, об/хв.

Електромагнітний момент генератора:

$$
M_{e}=\frac{P}{\varpi}
$$


3 формули електромагнітного моменту,

$$
M_{e}=\alpha_{i} \cdot A_{c p} \cdot B_{\delta c p} \cdot \pi \cdot D_{p}^{3} \cdot \lambda,
$$

визначається діаметр ротора генератора:

$$
D_{p}=\sqrt[3]{\frac{M_{e}}{\alpha_{i} \cdot A_{c p} \cdot B_{\delta c p} \cdot \pi \cdot \lambda}},
$$

де $\alpha_{i}-$ коефіцієнт полюсного перекриття; $A_{c p} \approx 13 \cdot 10^{3} \quad \mathrm{~A} / \mathrm{M}$ - лінійне навантаження; $B_{\delta c p} \approx 0,78$ Тл- середня величина індукції в робочому зазорі; $\lambda=\frac{l_{e}}{D_{p}}-$ відношення активної довжини ротора до його діаметра.

Таблиця 2. Очікувані параметри електрогенераторів на базі серійних асинхронних двигунів

\begin{tabular}{|c|c|c|c|c|c|c|c|c|}
\hline \multirow[b]{2}{*}{$v, M / c$} & & & ГСС-630K & ГСБ-630К & ГСБ-630М & ГСБ800 & СБ-1100 & ГСБ1100L \\
\hline & & & $\begin{array}{c}300 \text { кВт } \\
750 \text { об/хв }\end{array}$ & $\begin{array}{c}630 \text { кВТ } \\
750 \text { об/хв }\end{array}$ & $\begin{array}{c}800 \text { кВТ } \\
750 \text { об/хв }\end{array}$ & $\begin{array}{l}1000 \text { кВт } \\
750 \text { об/хв }\end{array}$ & $\begin{array}{l}2750 \text { кВТ } \\
750 \text { об/хв }\end{array}$ & $\begin{array}{l}3600 \text { кВт } \\
750 \text { об/хв }\end{array}$ \\
\hline \multirow{6}{*}{$\begin{array}{c}8 \\
\mathbf{M} / \mathbf{c}\end{array}$} & $S$ & $M^{2}$ & 3004 & 6309 & 8012 & 10015 & 52541 & 36054 \\
\hline & $D$ & $M$ & 61,8 & 89,6 & 101 & 113 & 187 & 214 \\
\hline & $\omega$ & $p a d / c$ & 1,81 & 1,25 & 1,1 & 0,97 & 0,6 & 0,53 \\
\hline & $n$ & об/ $/ x_{8}$ & 17,2 & 12 & 10,5 & 19 & 6 & 5 \\
\hline & $K_{\text {ped }}$ & - & 44 & 63 & 71 & 83 & 125 & 150 \\
\hline & $M_{e}$ & $H \cdot M$ & 166000 & 506000 & 719000 & 1000000 & 4500000 & 6700000 \\
\hline \multirow{6}{*}{$\begin{array}{l}12 \\
\mathrm{M} / \mathrm{c}\end{array}$} & $S$ & $M^{2}$ & 347 & 729 & 926 & 1157 & 1591 & 4166 \\
\hline & $D$ & $\mathcal{M}$ & 21 & 30 & 34 & 38 & 45 & 73 \\
\hline & $\omega$ & $p a d / c$ & 8 & 5,6 & 5 & 4,5 & 3,8 & 2,3 \\
\hline & $n$ & об/xв & 76 & 53,5 & 48 & 43 & 36 & 22 \\
\hline & $K_{\text {ped }}$ & - & 10 & 14 & 16 & 17 & 21 & 34 \\
\hline & $M_{e}$ & $H \cdot \mathcal{M}$ & 37500 & 112500 & 160000 & 222000 & 723000 & 156000 \\
\hline
\end{tabular}

Table 2. Expected parameters of electric generators based on mass-produced asynchronous (induction) motors

В табл. 2 використано такі позначення: $S$ - площа захопленої поверхні; $D$ - діаметр ротора; $\omega$ - кутова швидкість обертання ротора; $n$ - частота обертання ротора; $K_{\text {ред }}-$ коефіцієнт редукції; $M_{e}-$ електромагнітний момент генератора.

Як видно з табл. 2, параметри генераторів на швидкостях вітру $v=8 \quad$ м/с і $v=12 \quad$ м/с (прийняті для розрахунків в межах України та за кордоном відповідно), істотно відрізняються, оскільки потужність генераторів пропорційна швидкості вітру в третьому ступені. Так, наприклад, генератор потужністю 3600 кВт при швидкості вітру $8 \mathrm{~m} / \mathrm{c}$ і $12 \mathrm{~m} / \mathrm{c}$ матиме параметри, наведені в табл. 3 . 
Таблиця 3. Порівняння параметрів вітроустановки потужністю 3600 кВт при різних швидкостях вітру

Table 3. Wind turbine $(3600 \mathrm{~kW})$ parameters at different wind speed

\begin{tabular}{|l|c|c|}
\hline \multirow{2}{*}{\multicolumn{1}{|c|}{ Назва параметру }} & \multicolumn{2}{|c|}{ Швидкість вітру } \\
\cline { 2 - 3 } & $\mathbf{8} \mathbf{~ м / \mathbf { c }}$ & $\mathbf{1 2} \mathbf{~ м / \mathbf { c }}$ \\
\hline Частота обертання ротора, $o б / x в$ & 5 & 22 \\
\hline Електромагнітний момент, $H \cdot M$ & $6,7 \times 10^{6}$ & $1,56 \times 10^{6}$ \\
\hline Коефіцієнт редукції мультиплікатора & 150 & 34 \\
\hline Діаметр ротора, $M$ & 214 & 73 \\
\hline
\end{tabular}

Отже, синхронні електрогенератори зі збудженням від постійних магнітів та конструкції роторів з мультиплікаторами за масогабаритними розмірами та вартістю не співставні. Тому, ймовірно, доцільно робити вітроустановки в Україні з більшою висотою опор, але це буде призводити до зростання їхньої вартості та складнощів монтажу. Створення генераторів на базі серійних асинхронних двигунів спрощує їх виготовлення, але вимагає застосування мультиплікаторів, що своєю чергою викликає ряд недоліків: необхідність регулярного обслуговування, більша кількість деталей в агрегаті, зниження надійності. Тому був спроєктований, виготовлений i випробуваний протягом трьох років генератор потужністю 2 кВт оригінальної конструкції (рис. 3) у складі вітроустановки відповідної потужності. Особливість цього генератора в тому, що він $є$ модулем у складі головки, не має ярма статора, а його корпусом $є$ корпус самої головки і відсутній мультиплікатор.

В цілому за умови рівних потужностей сумарна маса генератора і мультиплікатора (в разі використання серійних асинхронних двигунів i мультиплікаторів) порівнянна з масою генератора без мультиплікатора. Відмінність буде полягати у геометричних співвідношеннях габаритних розмірів: у першому разі менший діаметр, але більший сумарний осьовий розмір генератора $\mathrm{i}$ мультиплікатора, у другому - більший діаметр генератора, але менший його осьовий розмір.
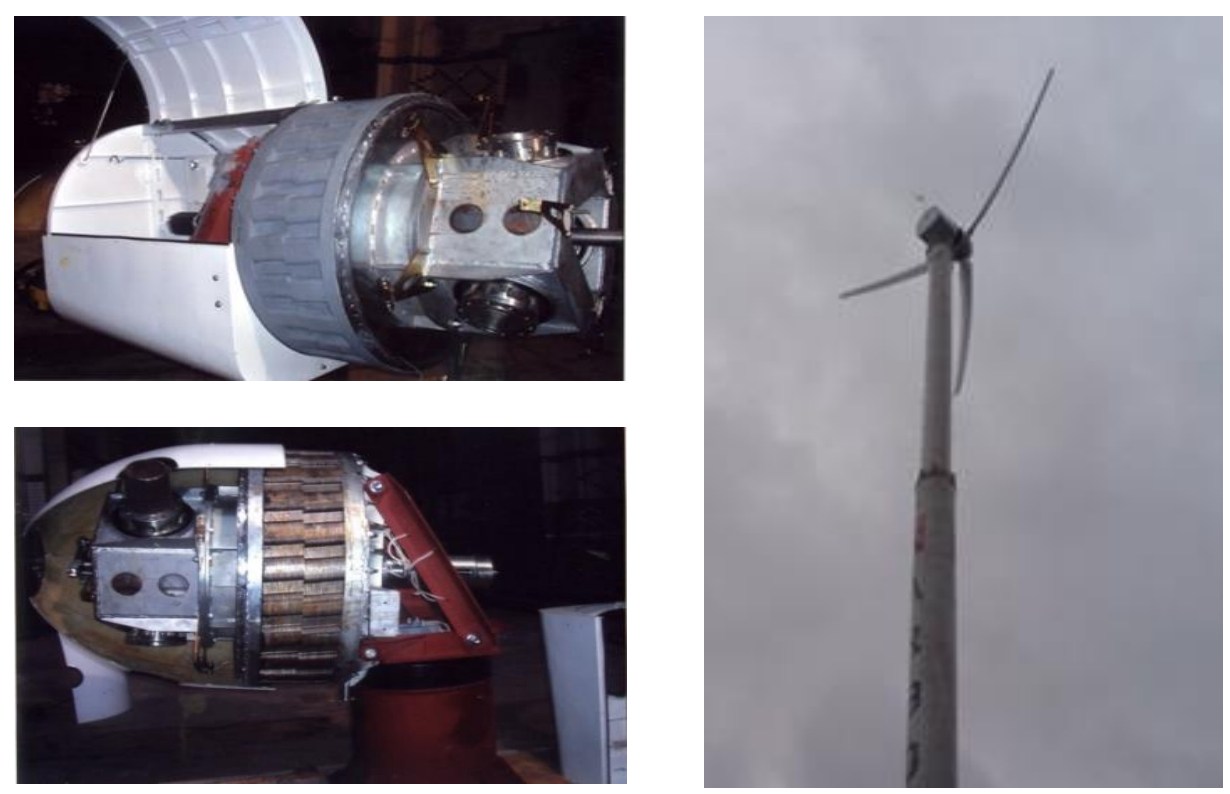

Рис. 3. Виготовлений безкорпусний безредукторний генератор для вітроустановки

Fig. 3. Frameless gearless generator for wind turbine 
Загальні характеристики розглянутих типів генераторів більш детально представлені в табл. 4, де наведені порівняльні параметри двох вітроустановок однакової потужності, 600 кВт, 3 асинхронним генератором і мультиплікатором - установки

«TURBOWINDS

Т600-48»

(випускалася серійно) - і розрахункові значення параметрів синхронного генератора без мультиплікатора зі збудженням від постійних магнітів $\mathrm{NdFeB}$ (див. рис. 3).

Таблиця 4. Порівняльні характеристики асинхронного генератора з трансмісісю / без трансмісії та синхронного зі збудженням від постійних магнітів при рівних потужностях

Table 4. Characteristics of an asynchronous generator with a transmission/synchronous generator with permanent magnets excitation without transmission and a at equal powers

\begin{tabular}{|c|c|c|c|c|}
\hline \multicolumn{3}{|c|}{ Характеристика генератора } & \multicolumn{2}{|c|}{ Тип генератора } \\
\hline \multicolumn{2}{|c|}{ Показник, позначення } & \multirow{2}{*}{$\begin{array}{c}\text { Од. } \\
\text { виміру } \\
\text { м/с }\end{array}$} & \multirow{2}{*}{$\begin{array}{c}\begin{array}{c}\text { асинхронний } 3 \\
\text { трансмісією }\end{array} \\
12\end{array}$} & \multirow{2}{*}{$\begin{array}{c}\text { синхронний } \\
\text { без трансмісії } \\
\text { зі збудженням від } \\
\text { постійних магнітів } \\
12\end{array}$} \\
\hline Швидкість вітру & $v$ & & & \\
\hline Кількість лопатей ротора & $N$ & од. & 3 & 3 \\
\hline Діаметр ротора & $D$ & $\mathrm{M}$ & 48 & 46 \\
\hline $\begin{array}{l}\text { Коефіцієнт швидкохідності } \\
\text { ротора }\end{array}$ & $\overline{Z^{\prime}}$ & - & 4,6 & 4,6 \\
\hline Частота обертання ротора & $n$ & об/хв & 24 & 24 \\
\hline $\begin{array}{l}\text { Номінальна потужність } \\
\text { вітроустановки }\end{array}$ & $P_{n}$ & кВт & 600 & 600 \\
\hline $\begin{array}{l}\text { Номінальна частота } \\
\text { обертання генератора }\end{array}$ & $n_{n}$ & об/хв & 1500 & 24 \\
\hline $\begin{array}{l}\text { Номінальний момент } \\
\text { генератора }\end{array}$ & $M_{n} \times 10^{3}$ & $\mathrm{H} \cdot \mathrm{M}$ & 4000 & 238 \\
\hline Номінальна фазна напруга & $U_{n}$ & $\mathrm{~B}$ & 690 & 690 \\
\hline Номінальний фазний струм & $I_{n}$ & A & 326 & 309 \\
\hline ККД генератора & $\eta$ & - & 0,90 & 0,96 \\
\hline Діаметр ротора генератора & $D p$ & M & 0,64 & 3,4 \\
\hline $\begin{array}{l}\text { Активна довжина ротора } \\
\text { генератора }\end{array}$ & $l_{a}$ & M & 0,74 & 0,2 \\
\hline $\begin{array}{l}\text { Діаметр корпусу } \\
\text { мультиплікатора }\end{array}$ & $D_{m}$ & M & 1,45 & - \\
\hline $\begin{array}{l}\text { Довжина корпусу } \\
\text { мультиплікатора }\end{array}$ & $L_{m}$ & M & 1,63 & - \\
\hline Маса генератора & $m_{g}$ & $\mathrm{~T}$ & 33 & 8 \\
\hline Маса мультиплікатора & $m_{m}$ & $\mathrm{~T}$ & 5,400 & - \\
\hline Загальна маса агрегату & $\sum m$ & $\mathrm{~T}$ & 8,4 & 8,1 \\
\hline Лінійне навантаження & $A \times 10^{3}$ & $\mathrm{~A} / \mathrm{M}$ & 8,2 & 10 \\
\hline Індукція в робочому зазорі & $B_{b}$ & Тл & 0,8 & 0,8 \\
\hline Коефіцієнт потужності & $\cos \varphi$ & - & 0,89 & 0,94 \\
\hline $\begin{array}{l}\text { Питомі втрати потужності } 3 \\
\text { поверхні корпусу без торців }\end{array}$ & $P_{p}$ & $\mathrm{KBT} / \mathrm{M}^{2}$ & 5,3 & 5,5 \\
\hline Загальна довжина агрегату & $L_{o}$ & M & 3 & 0,3 \\
\hline Діаметр корпусу генератора & $D_{k . g .}$ & $\mathrm{M}$ & 0,9 & 3,5 \\
\hline $\begin{array}{l}\text { Довжина корпусу } \\
\text { генератора }\end{array}$ & $L_{k . g}$ & м & 1,4 & 0,3 \\
\hline
\end{tabular}


Як видно з табл. 4, при рівних швидкостях вітру, однакових потужностях установок, геометричних розмірах і конструкціях роторів, порівнянних питомих електромагнітних навантаженнях генераторів $\left(\mathrm{A}, \mathrm{B}_{\mathrm{b}}\right)$ асинхронний генератор 3 мультиплікатором i синхронний генератор без мультиплікатора (безкорпусний) мають приблизно однакові маси, але при цьому істотно відрізняються габаритами. Перший має сумарний осьовий розмір $3 \mathrm{~m}$ при діаметрах корпусу генератора і корпусу мультиплікатора 0,9 м и 1,45 м відповідно; другий (безкорпусний) має діаметр корпусу 3,5 м та осьовий розмір $\mathrm{L}_{\mathrm{k.g}} \approx$ 1,4 м. Отже, враховуючи зазначені переваги такої конструкції, можна вважати іiі більш перспективною.

Висновки. 1. Проведено загальне порівняння параметрів вітроустановок різних конструкцій, які мають найбільше застосування.

2. Визначено перспективність використання постійних магнітів в системах збудження синхронних генераторів.

3. Дана оцінка можливості застосування серійних асинхронних двигунів 3 мультиплікаторами при створенні синхронних генераторів зі збудженням від постійних магнітів, наведені конструктивні особливості таких генераторів.

4. Проведено розрахунки параметрів синхронних вітроустановок при використанні серійних асинхронних двигунів ГСС i ДСБ потужністю від 300 до 3600 кВт, які випускаються ТОВ «Завод крупних електричних машин», м. Каховка; наведено алгоритм обчислення загальних параметрів машин при різних розрахункових швидкостях вітру для регіонів України $(8 \mathrm{~m} / \mathrm{c})$ і зарубіжних країн $(12 \mathrm{~m} / \mathrm{c})$.

5. Обгрунтовано доцільність застосування безкорпусної модульної конструкції вітроустановки зі збудженням від постійних магнітів без мультиплікатора.

6. Дана порівняльна оцінка параметрів серійного асинхронного генератора 3 мультиплікатором i генератора модульної конструкції зі збудженням від постійних магнітів.

1. Кудря С.О. та ін. Атлас енергетичного потенціалу відновлюваних джерел енергії України. Інститут відновлюваної енергетики НАН України. К. Віол принт. 2008. $55 \mathrm{c}$.

2. Кудря С.О., Перминов Ю.Н., Коханевич В.П. Патент на винахід №106673. Україна. МПК Н02К 16/00. Н02К 21/22. Вітроелектрична установка модульної конструкції. № а2013 01473. заявл. 07.02.13. опубл. 25.09.14, Бюл. №9.

3. Костенко М.П., Пиотровский Л.М. Электрические машины, Часть 2. М. Энергия. 1965. С. 43-55.

4. Перминов Ю.Н., Коханевич В.П., Шихайлов Н.А., Перминова С.Ю. Определение параметров и основных размеров генераторов для приливных электостанций малой мощости (до 1000 кВт). Відновлювана енергетика. 2017. № 3 (50). C. 66-72.

5. Кудря С.А., Перминов Ю.Н., Буденный В.Ф. О методах расчета магнитных систем с постоянными магнитами. Відновлювана енергетика. 2009. № 4 (19). С.4043.

6. Балагуров В.А., Галтеев Ф.Ф., Ларионов А.Н. Электрические машины с постоянными магнитами. М. Энергия. 1964. $208 \mathrm{c}$

7. Арнольд Р.P. Расчет и проектирование магнитных систем с постоянными магнитами. М. Энергия. 1969. 260 с.

8. Буль Б.К. Основы теории и расчета магнитных цепей. М. Энергия. 1964. 254 с.

9. Перминов Ю.Н., Монахов Е.А. Сравнение вариантов конструкций синхронных генераторов с возбуждением от постоянных магнитов для ветроустановок. Відновлювальна енергетика. 2019. № 2. С. 54-60.

\section{REFERENCES}

1. Kudrya $\quad$ S. Atlas enrgetichnogo potentsialu vidnovliuvanikh dzherel energiï Ukraïni. [Atlas of energy potential of reneweble energy sources in Ukraine]. Institute for Renewable Energy of the National Academy of Sciences of Ukraine. K. Viol print. 2008. 55 p. [in Ukrainian].

2. Kudrya S.O., Perminov Yu.M., Kokhanevich V.P. Patent na vinakhid №106673. Ukrayina. MPK Н02K 16/00. H02K 21/22. Vitroelektrichna ustanovka modulnoi konstruktsiï. № a2013 01473. [Patent for invention No.106673.Ukraine. IPC H02К 16/00. Н02К 21/22. Windmill installation of modular construction. No. a2013 01473]. Stated 07.02.13. published 25.09.14, Bul. №9. [in Ukrainian].

3. Kostenko M.P., Piotrovskii L.M. Elektricheskie mashiny, Chast 2. [Electrical Machines. Part 2]. Moscow. Russia, «Energiya» publishing. 1965. Pp. 43-55. [in Russian]. 
4. Permynov Y., Kokhanevich V., Shikhailov N., Permynova $S$. Opredelenie parametrov i osnovnyih razmerov generatora dlya prilivnyih elektrostantsiy maloy moschnosti (do $1000 \mathrm{kVt}$ ). [Determination of parameters and basic dimensions of the generator for low power tidal plants (up to $1000 \mathrm{~kW}$ )]. Vidnovluvana energetika. 2017. No. 3 (50). Pp. 46-59. [in Russian].

5. Kudrya S.A., Perminov Yu.N., Budennyi V.F. O metodakh rascheta magnitnykh sistem $\mathrm{s}$ postoyannymi magnitami. [On methods for calculating magnetic systems with permanent magnets]. Vidnovlyuvana energetika. 2009. No. 4(19). Pp. 40-43. [in Russian].

6. Balagurov V.A., Galteev F.F., Larionov A.N. Elektricheskie mashiny $\mathrm{s}$ postoyannymi magnitami. [Electric machines with permanent magnets]. Moscow. Russia. «Energiya» publishing. 1964. 208 p. [in Russian].

7. Arnold R.R. Raschet i proektirovanie magnitnykh sistem s postoiannymi magnitami [Calculation and design of magnetic systems with permanent magnets]. Moscow. Russia. «Energiya» publishing. 1969. 260 p. [in Russian].

8. Bull B.K. Osnovy teorii i rascheta magnitnykh tsepei. [Fundamentals of the theory and calculation of magnetic circuits]. Moscow. Russia. «Energiya» publishing. 1964. 254 p.

[in Russian].

9. Perminov Yu.M., Monakhov E.A. Sravnenie variantov konstruktsii sinkhronnykh generatorov $\mathrm{s}$ vozbuzhdeniem ot postoiannykh magnitov dlia vetroustanovok. [Comparison of design options for synchronous generators with excitation from permanent magnets for wind turbines]. Vidnovlyuvana energetika. 2019. No. 2. Pp. 54-60. [in Russian].

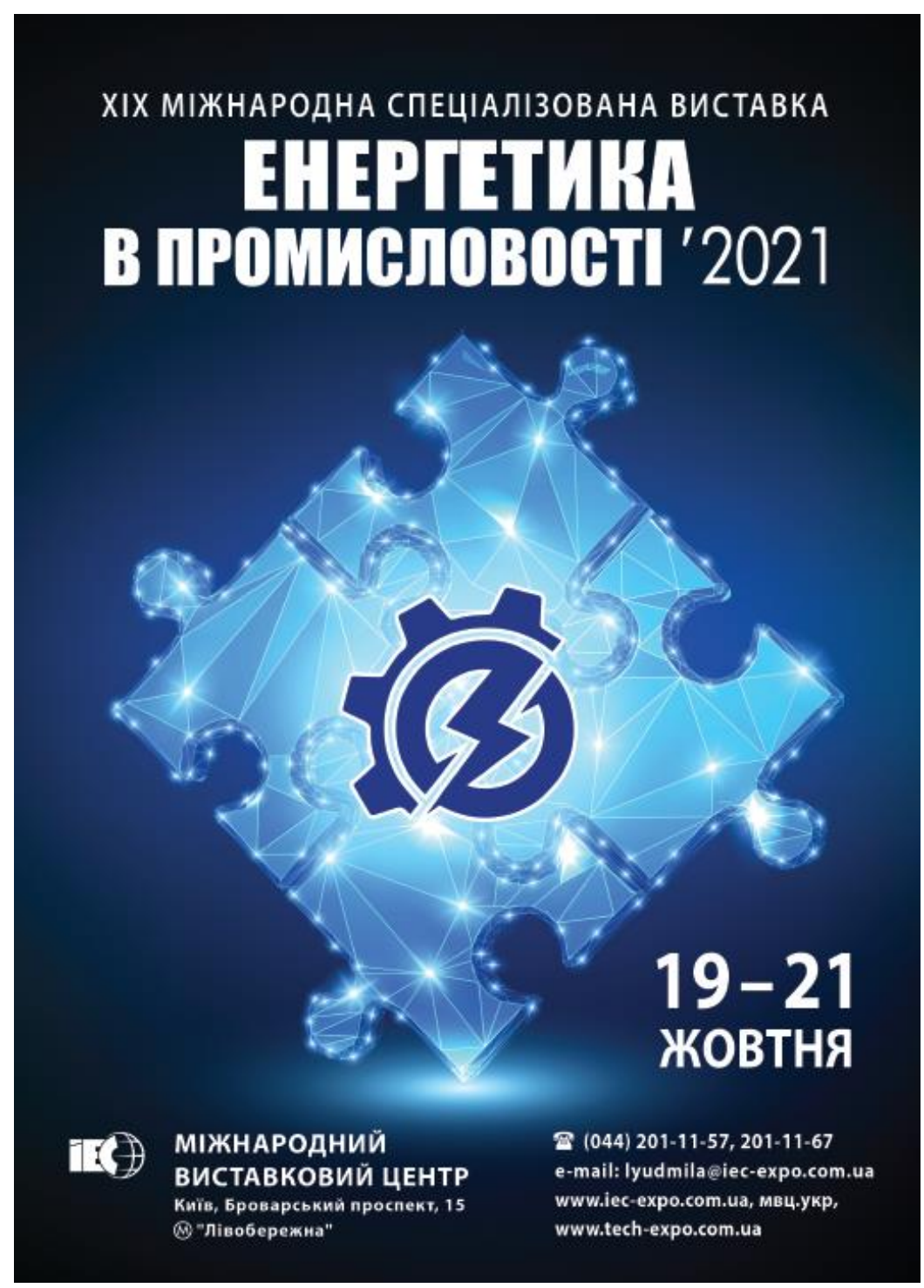

